\title{
Ex-libris
}

\section{RESEÑA DEL CATÁLOGO DEL FOTÓGRAFO W. RUNCIE STOCKHAUSEN}

Si para ser artista es requisito asumir la vida como una auténtica aventura entonces la de Walter $\mathrm{O}$. Runcie cumple sobradamente esa exigencia. A continuación brindamos un apretado resumen de esa biografía única que resulta suficientemente elocuente de las vicisitudes que acuñan la obra de los grandes artistas y que nos permitirá comprender el valor de ese acervo documental y la contribución que el catálogo, recientemente editado, constituye para los investigadores.

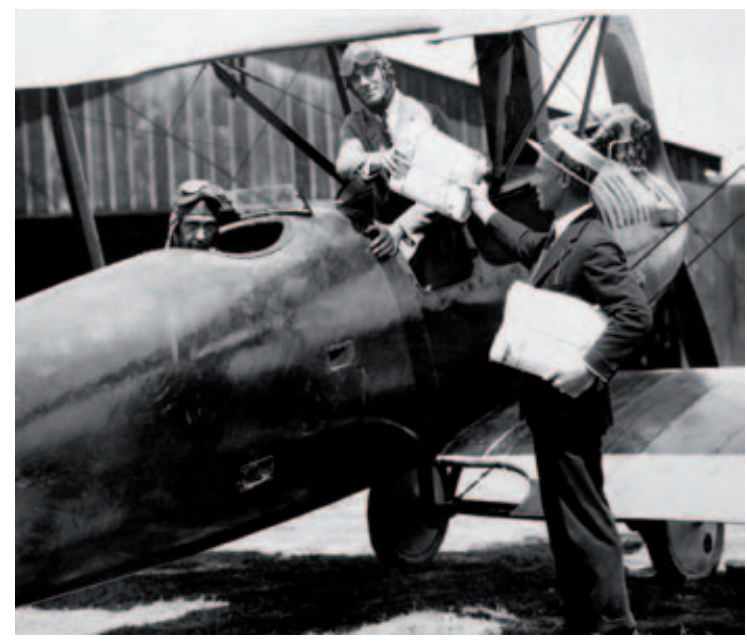

Walter O. Runcie Stockhausen na-

ció en Jamaica, en 1881, hijo de Walter Runcie, pastor anglicano y farmacéutico escocés, y de Caroline Louise Stockhausen, de nacionalidad alemana ${ }^{1}$. Sustentará sus estudios técnicos de mecánica y electricidad en Chicago y Filadelfia trabajando como operador de cine y como asistente de filmación de reportajes para noticieros como Breaking News. Desde este momento empieza a labrar su reputación de buen fotógrafo.

A partir de 1907, también en Chicago, se inicia en la aviación formando parte del Aero Club de Illinois y haciéndose miembro -con el carnet número 8- del Aéro-Club de France, el primer aeroclub en el mundo. En 1910 construyó una copia exacta del monoplano que Louis Blériot usó para cruzar el Canal de la Mancha. (Esta "curiosidad" lo llevó a realizar, más adelante, "inventos relacionados con la técnica fotográfica" para lo cual se suscribió al Chartered Institute of American Inventors en Washington D. C.).

Será en este lapso que su vocación por el manejo de las cámaras fotográficas y cinematográficas y su vocación aeronáutica hallarán la confluencia precisa: empezará a filmar y

1 Toda la información biográfica así como la imagen que ilustra esta reseña nos la proporcionó Carlos Runcie Tanaka, depositario del Archivo Walter O. Runcie (AWOR). 
tomar imágenes en movimiento viajando por todo el mundo aprovechando al máximo sus posibilidades de capturar imágenes desde los puntos de vista insólitos que la aeronave le otorga.

Se convertirá luego en realizador cinematográfico contratado por C. L. Chester Productions lo que lo llevará a viajar por los Estados Unidos, Canadá, Europa, el Norte de África y América del Sur, realizando simultáneamente vistas aéreas "fijas" y filmaciones².

Visita el Perú por primera vez en 1919 donde regresará cinco años después -sin sospechar que iba a vivir entre nosotros el resto de su vida- comisionado por "la productora de cine C. L. Chester de Nueva York para realizar una serie de filmaciones para el gobierno peruano" registrando las islas guaneras, el trazo del Ferrocarril Central y los sembríos destinados a las industrias algodoneras y azucareras del país.

Posteriormente trabajará, contratado por Augusto B. Leguía, para realizar inspecciones aéreas de los valles del norte peruano "como parte del gran proyecto de irrigación de Olmos" y hará levantamientos aerofotogramétricos de varias ciudades para la Marina del Perú. Será el organizador de la primera Escuela de Fotografía Aérea en la Base de Ancón sentando las bases del Servicio Aerofotográfico Nacional.

En 1925 Elmer J. Faucett y Walter O. Runcie llevan el primer correo aéreo del Perú a Chiclayo, donde entregan el diario La Prensa, transportado en el avión Curtiss Oriole de 150 HP de propiedad de Faucett. (Más adelante Runcie hará una abertura en el piso de su propia aeronave para instalar su cámara aérea).

En 1926, contratado por The Standard Oil Co. of Peru, realiza el registro fotográfico del camino del río Pichis y las rutas fluviales del Pachitea y Ucayali y en 1927 hace el registro de las instalaciones de la compañía transnacional Cerro de Pasco Copper Corporation en La Oroya, Cerro de Pasco y Morococha.

En 1931 forma parte de la expedición fotográfica aérea del Perú Shippee-Johnson cuyo periplo se publicará en la edición de The National Geographic Magazine de enero de $1933^{3}$. En 1937 es el fotógrafo asistente de la expedición Hayden Planetarium-Grace Eclipse Expedition al Perú, organizada por The American Museum of Natural History (AMNH) para la cual se encarga de registrar el eclipse solar del 8 de junio de 1937 junto con el grupo de científicos de la misión norteamericana.

En 1931 funda la empresa "W. O. Runcie" con oficinas en el sexto piso del Edificio Wiese, en el centro de Lima y en 1935 funda la casa de fotografía "Runcie Graphs", la primera dedicada a la realización de copias fotostáticas en el Perú y a la comercialización de fotomurales y ampliaciones. "Runcie Graphs" permanecería activa hasta principios de los ochentas.

Entre 1940 y 1941 trabaja como fotógrafo en la Sexta Expedición Michael Lerner auspiciada por el The American Museum of Natural History (AMNH), con el interés de encontrar el merlín negro en las aguas de Cabo Blanco (Perú) y de Tocopilla (Chile).

El 14 de septiembre de 1957 el Ministro de Aeronáutica del Perú le otorga la medalla conmemorativa "Jorge Chávez Dartnell".

Fallece en Lima el 21 de setiembre de 1966. Sus restos se encuentran en el Cementerio Británico.

2 Hacia 1917 se desempeñó como corresponsal de guerra, fue tomado prisionero por el ejército turco y liberado por intermediación del servicio diplomático de los EE.UU.

3 "Air Adventures in Peru, Cruising among Andean Peaks, Pilots and Cameramen Discover Wondrous Works of an Ancient People." Robert Shippee menciona a W. O. Runcie como fotógrafo asistente y camarógrafo de la misión. En 1932 realiza la película Wings over the Andes, AMNH Film, producida por Robert Shippee, y auspiciada por American Geographical Society y The American Museum of National History (AMNH). Walter O. Runcie es el camarógrafo del documental. El filme está en el archivo del AMNH. 